\title{
PERANCANGAN SISTEM INFORMASI PENILAIAN KINERJA KARYAWAN SPG BERSTATUS KONTRAK PADA PT. SOFTEX INDONESIA MENGGUNAKAN METODE SIMPLE ADDITIVE WEIGHTING (SAW)
}

\author{
Nur Azizah ${ }^{1}$ \\ Sri Rahayu ${ }^{2}$ \\ Nova Adhista ${ }^{3}$ \\ Dosen STMIK RAHARJA ${ }^{1,2}$ \\ STMIK RAHARJA Jurusan Sistem Informasi ${ }^{3}$ \\ Jl. Jendral Sudirman No. 40, Modernland, Tangerang ${ }^{1,2,3}$ \\ E-mail: nur.azizah@ raharja.info ${ }^{1}, \underline{\text { srirahayu@ raharja.info }}^{2}$, nova@ raharja.info $^{3}$
}

\begin{abstract}
ABSTRAK
Di era globalisasi persaingan ekonomi saat ini setiap perusahaan akan selalu berupaya untuk menerapkan suatu sistem informasi yang efesien dan efektif dalam rangka mencapai tujuan perusahaan salah satunya dalam hal pengembangan sumber daya manusia. Dalam bidang pemasaran terdapat suatu bagian sumber daya manusia yang memiliki keterkaitan langsung dengan konsumen, yaitu pada bagian sales product atau disebut dengan Sales Promotion Girls (SPG). Sales Promotion Girl (SPG) yang bekerja pada PT. Softex Indonesia mempunyai status karyawan kontrak. Seorang SPG dapat menjadi karyawan tetap jika memenuhi kriteria sesuai dengan aturan perusahaan. Sistem penilaian kinerja SPG yang berjalan saat ini masih manual dan hasil penilaian seringkali tidak akurat. sehingga karyawan yang terpilih sering kali tidak sesuai harapan dan kriteria yang dibutuhkan perusahaan, Untuk mengatasi masalah diatas maka dibutuhkan sebuah system baru yang terkomputerisasi dan perhitungannya secara sistematis menggunakan metode Simple Additive Weighting (SAW). Metode pengumpulan data menggunakan metode observasi, wawancara, dan studi pustaka, Unified Modelling Language (UML), perangkat lunak yang digunakan dalam pembuatan system ini menggunakan bahasa pemrograman PHP dan database menggunakan MySQL. Hasil akhir dari penelitian ini berupa aplikasi Sistem Penilaian Kinerja SPG yang efektif dan memiliki hasil yang akurat.
\end{abstract}

Kata Kunci:Penilaian Kinerja, SPG, SAW

\begin{abstract}
In the current era of globalization of economic competition every company will always strive to implement an efficient and effective information system in order to achieve the company's goals one of them in terms of human resource development. In the field of marketing there is a part of human resources that have a direct relationship with consumers, namely on the sales product or called Sales Promotion Girls (SPG). Sales Promotion Girl (SPG) working at PT. Softex Indonesia has contract employee status. An SPG may become a permanent employee if it meets the criteria in accordance with company rules. The current SPG performance appraisal system is still manual and the assessment results are often inaccurate. So that the selected employees often do not match the expectations and criteria required by the company, To overcome the above problems then required a new system that is computerized and calculated systematically using Simple Additive Weighting (SAW) method. Methods of data collection using observation methods, interviews, and literature study, Unified Modeling Language (UML), software used in the manufacture of this system using PHP programming languages and databases using MySQL. The end result of this research is the application of SPG Performance Appraisal
\end{abstract}


System that is effective and has accurate results.

Keywords: Performance Assessment, SPG, SAW

\section{PENDAHULUAN}

Di era globalisasi persaingan ekonomi yang saat ini semakin pesat dan kemajuan teknologi yang modern, salah satunya adalah penerapan sistem informasi pada perusahaan maka kebutuhan informasi merupakan salah satu faktor yang sangat penting. Setiap perusahaan akan selalu berusaha menjaga usahanya agar tetap dapat bertahan dan berkembang maka perlu upaya penyempurnaan, meliputi peningkatan, produktifitas cepat waktu serta mudah dipahami untuk penyampaian tujuan perusahaan dalam segala bentuk persaingan. Salah satunya adalah dalam bidang pemasaran produk. Pemasaran suatu produk memerlukan beberapa aktivitas yang melibatkan berbagai sumber daya. Sebagai fenomena yang berkembang saat ini, dalam pemasaran terdapat suatu bagian yang memiliki keterkaitan langsung dengan konsumen, yaitu pada bagian sales product atau disebut dengan Sales Promotion Girls (SPG). Salah satu peningkatan penjualan produk perusahaan secara tidak langsung dilakukan oleh Sales Promotion Girls, dikarenakan tugas dari Sales Promotion Girls adalah memasarkan produk perusahaan.

Sales Promotion Girl (SPG) yang bekerja pada PT. Softex Indonesia mempunyai status karyawan tidak tetap atau disebut kontrak. Dimana SPG tersebut dapat bekerja selama hubungan kerja sama masih berjalan. Namun jika kerja sama telah berakhir, otomatis sesuai kesepakatan, SPG tersebut tidak dapat bekerja lagi pada PT. Softex Indonesia. Ada beberapa hal atau syarat serta kemungkinan seorang SPG dapat menjadi karyawan tetap pada PT. Softex Indonesia, salah satunya yaitu SPG tersebut sudah sampai pada kontrak yang terakhir dan memenuhi kriteria sesuai dengan aturan perusahaan. Karena hal itu, tidak semua SPG dapat menjadi karyawan tetap harus ada penyeleksian dari seorang pimpinan. Sistem penilaian kinerja yang berjalan saat ini masih mengunakan formulir manual dan bisa memberikan ruang adanya penilaian yang hanya berdasarkan objektifitas saja oleh pimpinan perusahaan sehingga karyawan yang terpilih sering kali tidak memenuhi kriteria yang dibutuhkan perusahaan, sehingga karyawan yang terpilih tersebut tidak dapat bekerja secara maksimal karena kurangnya kemampuan.

\section{PERMASALAHAN}

Sistem penilaian kinerja SPG pada PT. Softex Indonesia yang berjalan saat ini masih mengunakan formulir manual,sehingga bisa memberikan ruang adanya penilaian yang hanya berdasarkan objektifitas saja oleh pimpinan perusahaan dan hasilnya karyawan yang terpilih sering kali tidak memenuhi kriteria yang dibutuhkan perusahaan dan karyawan yang terpilih tersebut tidak dapat bekerja secara maksimal karena kurangnya kemampuan.

Untuk mengatasi hal tersebut diatas perlu adanya sebuah sistem penilaian kinerja yang terkompuetrasi dan menggunakan metode penilaian yang sudah teruji untuk keakuratannya sehingga hasilnya karyawan yang terpilih sebagai karyawan tetap benar-benar sesuai dengan spesifikasi dan kriteria yang di butuhkan oleh perusahaan. 


\section{HASIL DAN PEMBAHASAN}

Sistem penilaian kinerja yang berjalan saat ini pada PT. Softex Indonesia masih mengunakan formulir manual dan hanya ada dua faktor saja yang dinilai yaitu target penjualan dan absensi. Berdasarkan observasi yang di lakukan peneliti maka dirancang sebuah sistem penilaian yang terkomputerisasi dan bebasis Web Server dengan metode penilaian kinerja menggunakan Simple Additive Weighting (SAW) atau penjumlahan terbobot.

Metode SAW (Simple Additive Weighting) adalah suatu metode yang digunakan untuk mencari alternatif optimal dari sejumlah alternatif dengan kriteria tertentu. Inti dari SAW adalah menentukan nilai bobot untuk setiap atribut, kemudian dilanjutkan dengan proses perankingan yang akan menyeleksi alternatif yang sudah diberikan. Pada dasarnya, ada 3 pendekatan untuk mencari nilai bobot atribut, yaitu pendekatan subyektif, pendekatan obyektif dan pendekatan integrasi antara subyektif \& obyektif. Masing masing pendekatan memiliki kelebihan dan kelemahan. Pada pendekatan subyektif, nilai bobot ditentukan berdasarkan subyektifitas dari para pengambil keputusan, sehingga beberapa faktor dalam proses perankingan alternatif bisa ditentukan secara bebas. Sedangkan pada pendekatan obyektif, nilai bobot dihitung secara matematis sehingga mengabaikan subyektifitas dari pengambil keputusan (Kusumadewi, et al., 2006)

Untuk mementukan SPG yang berhak untuk diangkat sebagai karyawan tetap disusun dengan menggunakan langkah-langkah sebagai berikut:

1. Penentuan kriteria-kriteria yang akan dijadikan acuan dalam pengambilan keputusan. kriteria-kriteria dan pembobotan untuk setiap kriteria yang akan dijadikan acuan dalam pengambilan keputusan adalah sebagai berikut:

Tabel Kriteria

Tabel 1 Tabel Kriteria

\begin{tabular}{|l|l|l|l|}
\hline Code & $\begin{array}{l}\text { Faktor Yang } \\
\text { Dinilai }\end{array}$ & Kriteria & $\begin{array}{l}\text { Bobot Per } \\
\text { Faktor }\end{array}$ \\
\hline C1 & Performance & Sangat Baik & $35 \%$ \\
\hline C2 & Knowlage & Baik & $25 \%$ \\
\hline C3 & $\begin{array}{l}\text { Communication } \\
\text { Skill }\end{array}$ & Baik & $25 \%$ \\
\hline C4 & Body Language & Cukup & $15 \%$ \\
\hline C5 & Attitude & Cukup & $15 \%$ \\
\hline
\end{tabular}

Tabel Nilai Dan Bobot Untuk Kriteria

Tabel 2 Nilai Dan Bobot Untuk Kriteria

\begin{tabular}{|l|l|l|l|}
\hline CI s.d C5 & \multicolumn{2}{l|}{} \\
\hline Nilai & Bobot & Nilai Kriteria & Keterangan \\
\hline $80-100$ & $35 \%$ & 5 & Sangat Baik \\
\hline $60-79$ & $25 \%$ & 4 & Baik \\
\hline $40-59$ & $15 \%$ & 3 & Cukup \\
\hline $20-39$ & $5 \%$ & 2 & Buruk \\
\hline
\end{tabular}




\begin{tabular}{|l|l|l|l|}
\hline $0-19$ & $0 \%$ & 1 & Sangat Buruk \\
\hline
\end{tabular}

2. Merekap hasil penilaian dari setiap alternatif (karyawan yang di nilai)

3. Pembentukan matriks dari nilai yang di dapat dan mengkonversinya ke bobot yang sudah di tentukan dalam tabel 1.

4. Menghitung normalisasi dari setiap alternative dengan rumus sebgai berikut:

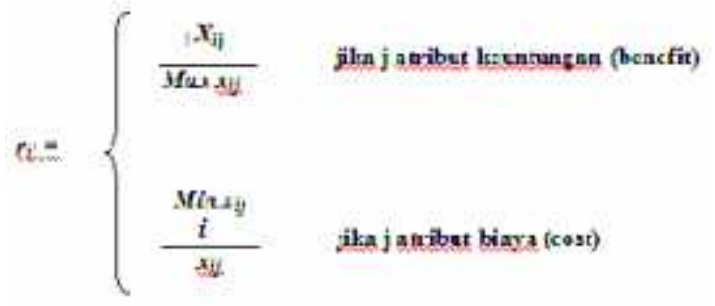

5. Mencari perangkingan atau nilai terbaik dengan mengkalikan hasil normalisasi untuk setiap kriteria dengan bobot per factor yang sudah di terntukan untuk permasing-masing faktor seperti pada Tabel 3.1 dengan rumus sebagai berikut:

$$
\begin{aligned}
\mathrm{Vi} & =\sum \mathrm{W}_{\mathrm{j}} \text { rij } \\
\mathrm{J}=1 & \\
\mathrm{Vi} & =\text { nilai prefensi } \\
\mathrm{wj} & =\text { bobot rangking } \\
\mathrm{rij} & =\text { rating kinerja ternormalisasi }
\end{aligned}
$$

\section{LITERATURE REVIEW}

Literature adalah kesusasteraan atau kepustakaan, sedangkan review adalah suatu tindakan meninjau, memeriksa kembali suatu hal yang telah dikerjakan sebelumnya sehingga dalam literature review dapat disimpulkan sebagai suatu tindakan memeriksa dan meninjau kembali suatu kepustakaan.

Dalam upaya mengembangkan dan menyempurnakan pengembangan ini perlu dilakukan study pustaka (literature review) sebagai salah satu dari penerapan metode penelitian yang dilakukan, diantaranya sebagai berikut :

1. Penelitian yang dilakukan oleh Safizal (2015) yang berjudul "Metode AHP Dalam Penilaian Kinerja Sales Promotion Girl". Dalam penelitian ini terdapat kesimpulan bahwa dengan Metode AHP dalam menilai kinerja SPG maka dapat diperoleh hasil evaluasi kinerja SPG yang memiliki bobot prioritas yang paling tinggi untuk menunjang kinerja perusahaan. Sehingga perusahaan lebih mudah dalam menilai kinerja SPG yang terbaik dalam memasarkan produk perusahaan sehingga bisa meningkatkan pendapatan perusahaan.

2. Penelitian yang dilakukan oleh Sri Rahayu (2015) yang berjudul "Sistem Persediaan Alat Tulis Kantor Sebagai Penunjang Pengambilan Keputusan Bagian Logistic di Perguruan Tinggi Raharja” dalam penelitianini dapat disimpulkan Masalah yang ada dapat dipecahkan dengan adanya rancangan sistem informasi persediaan alat tulis kantor pada Perguruan Tinggi Raharja berbasis web yang dapat memberikan pelayanan informasi yang akurat, tepat waktu dan sesuai dengan kebutuhan yang diinginkan bagian logistik 
maupun divisi lainnya sebagai pengguna barang. Sistem yang belum terkomputerisasi belum bisa menghasilkan laporan yang efisien karena pengolahan datanya belum tersimpan dalam database server sehingga pekerjaan dilakukan berulang-ulang. Dengan sistem informasi Persediaan Alat Tulis Kantor setiap transaksi yang terjadi setiap harinya secara otomatis digeneralisasi ke laporan dengan cepat dan akurat. Dengan kecepatan dan keakuratan informasi yang diterima bagian logistic.

3. Penelitian yang dilakukan oleh Ariyanto (2012) yang berjudul "Sistem Pendukung Keputusan Pemilihan Karyawan Terbaik Dengan Metode Simple Additive Weighting (SAW) Studi Kasus Pamella Swalayan". Dalam penelitian ini dapat disimpulkan bahwa penulis berhasil menghasilkan sistem yang dapat membantu dalam pemecahan masalah terutama pada pengambilan keputusan pemilihan karyawan terbaik di swalayan Pamela tersebut dengan menggunakan metode Simple Additive Weighting (SAW) sehingga sistem tersebut dapat memberikan solusi rekomendasi karyawan terbaik kepada user (pengguna) sesuai dengan bobot dan criteria yang di tentukan diawal sebelum perhitungan.

4. Penelitian yang dilakukan oleh Ignatius Joko Dewanto (2016) yang berjudul "Membangun Sistem Penunjang Keputusan Untuk Investasi Saham Dengan Metode Simple Additive Weighting (SAW)". dalam penelitianini dapat disimpulkan bahwa Pembangunan sistem penunjang keputusan yang dihasilkan pada penelitian ini menerapkan metode SAW dalam mendeskripsikan investasi saham sesuai dengan unit kinerja saham yang dimiliki di setiap perusahaan. Dan dengan adanya aplikasi sistem penunjang keputusan dengan sistem perhitungan yang baku dalam melakukan penilaian investasi saham dapat menampilkan hasil perbandingan dari setiap saham-saham yang akan direkomendasikan untuk penentuan pemilihan saham dapat digunakan sebagai alat pendukung keputusan seorang pialang dalam berinvestasi.

\section{PEMECAHAN MASALAH}

\section{Use Case Diagram Pada Sistem Penilaian Kinerja SPG}

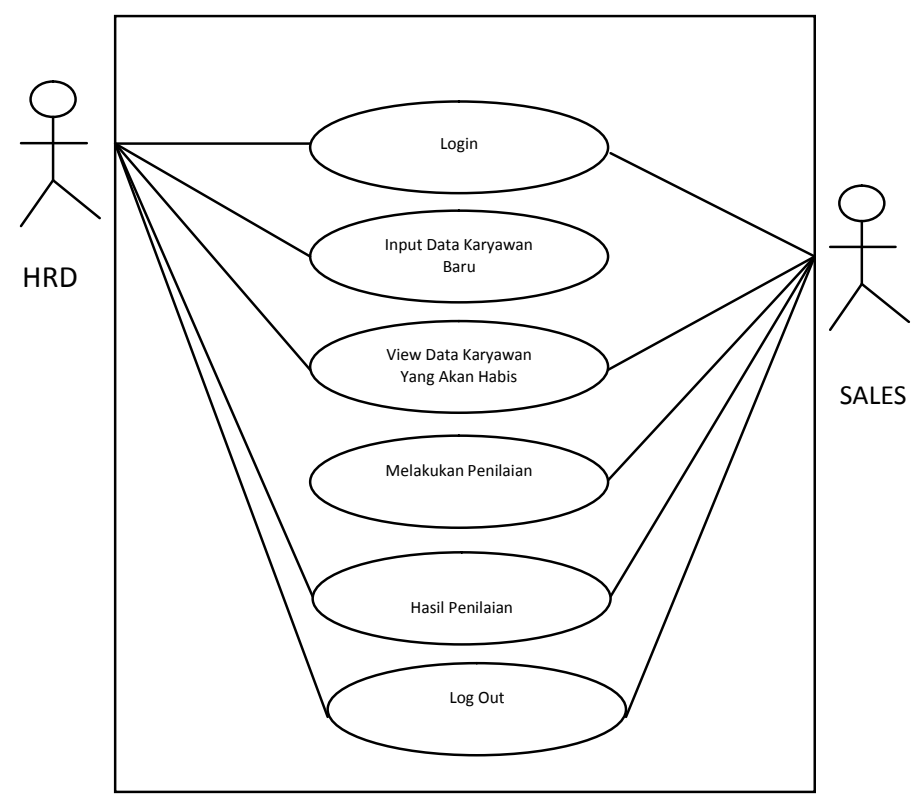

Gambar 1 Use Case Diagram Sistem 
Gambar use case diatas merupakan satu sistem yang mencangkup seluruh kegitan dalam melakukan penilaian kinerja SPG dimana ada dua aktor di didalamnya yaitu HRD dan Sales. Berikut adalah untuk penjelasan per use case yang ada pada gambar diatas. Ada beberapa prosedur sistem yang harus di jalankan oleh HRD ataupun Sales yaitu sebagai berikut:

1. HRD melakukan input data karyawan yang baru masuk

2. Sebelum melakukan penilaian HRD dan Sales sama-sama akan melihat terlebih dahulu karyawan yang kan habis masa kontraknya di bulan depan (karyawan yang akan dinilai)

3. Sales melakukan penilaian karyawan SPG

4. HRD dan Sales sama-sama akan melihat hasil penilian guna di tidaklanjuti hasil, apabila diangkat karyawan tetap maka HRD akan membuatkan Surat Keputusannya dan apabila tidak maka Sales akan menginformasikan kepada SPG yang bersangkutan.

\section{IMPEMENTASI}

\section{User Interface Aplikasi}

\section{Menu Login}

Pada saat user akan mengakses aplikasi maka hal yang pertama kali di lakukan adalah memasukan user name dan password supaya bisa masuk ke aplikasi, tampilan halaman tersebut seperti pada gambar 1 di bawah ini.

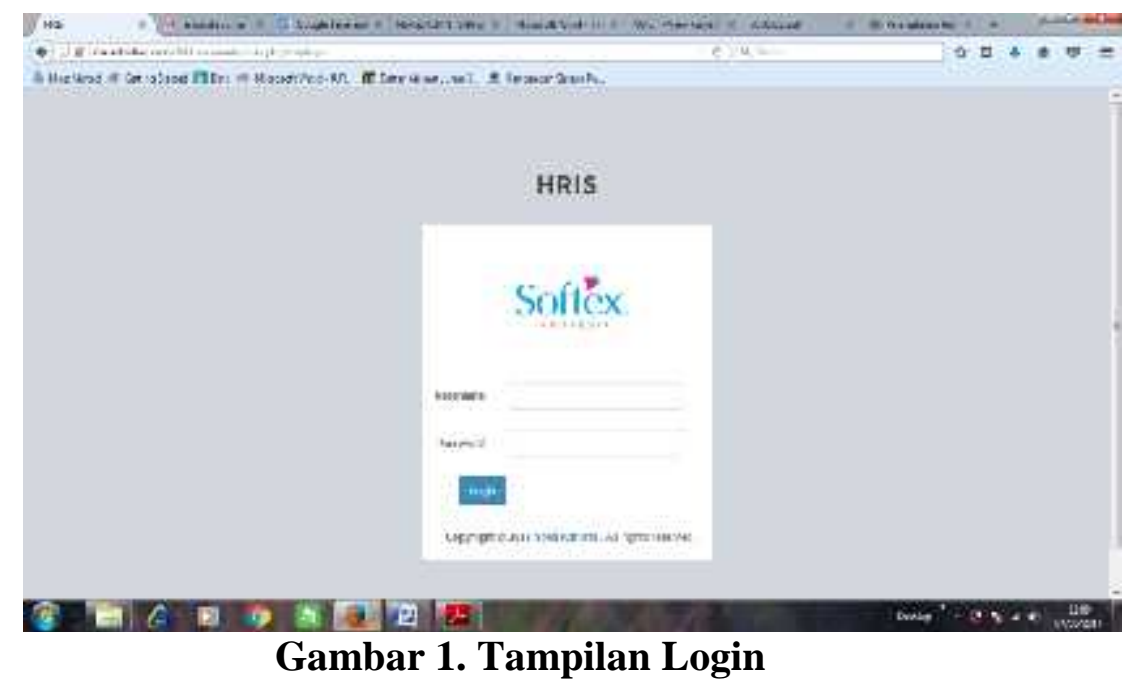

\section{Input Data Karyawan}

Form ini digunakan untuk melakukan pengisian data karyawan kontrak SPG yang ada di perusahaan. Data karyawan yang diisi berupa No. ID, nama, alamat serta pendidikan terakhir karyawan kontrak SPG. Adapun tampilan form isiannya terlihat pada Gambar 2. dibawah ini. 


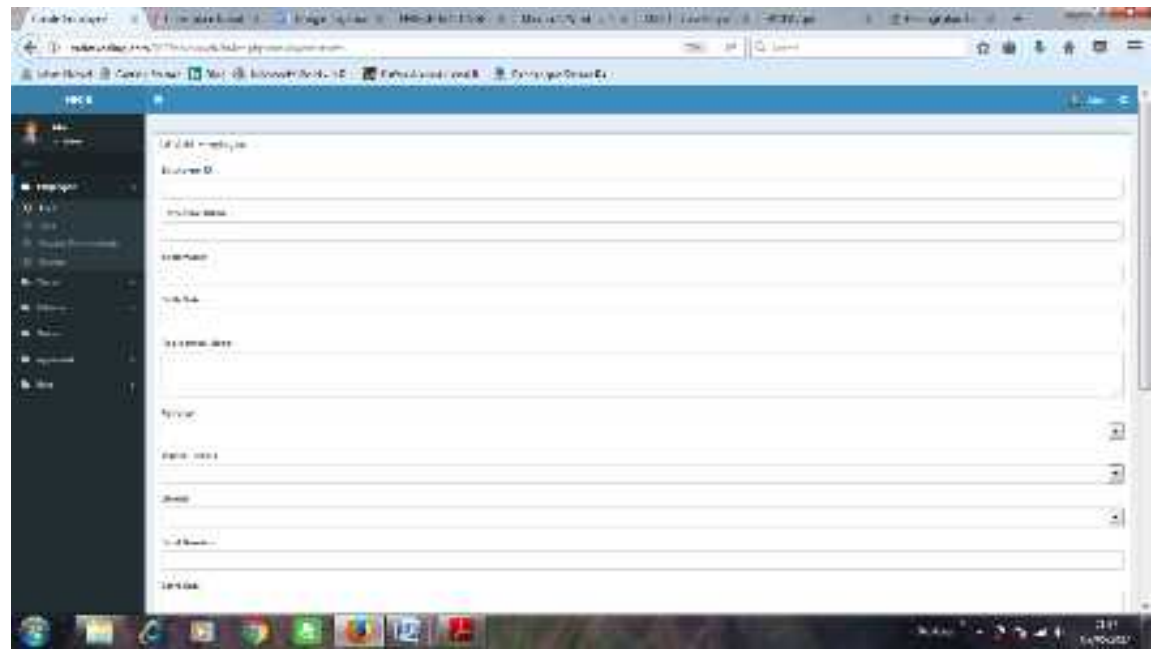

Gambar 2. Tampilan Input Karyawan

\section{Data Penilaian}

Form ini digunakan untuk memasukkan nilai yang didapat karyawan kontrak SPG dari setiap kriteria yang telah ditentukan perusahaan. Adapun tampilan form isiannya dapat dilihat pada Gambar 3.

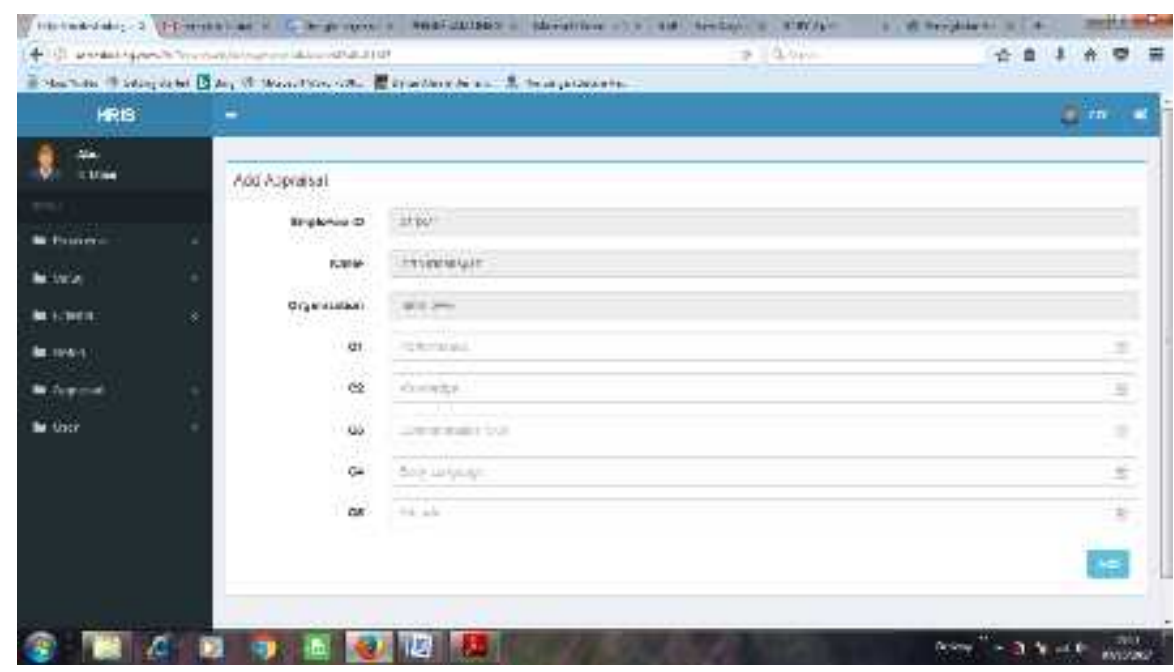

\section{Gambar 3. Tampilan Penilaian}

\section{Tampilan Hasil Penilaian}

Form ini menampilkan nilai-nilai yang telah dimasukkan kedalam sistem, yang selanjutnya akan dilakukan proses perankingan, sehingga dapat dilihat siapa yang mendapatkan nilai tertinggi dan berhak lolos sebagai karyawan tetap pada PT. Softex Indonesia. Adapaun tampilannya dapat dilihat pada Gambar 4. 


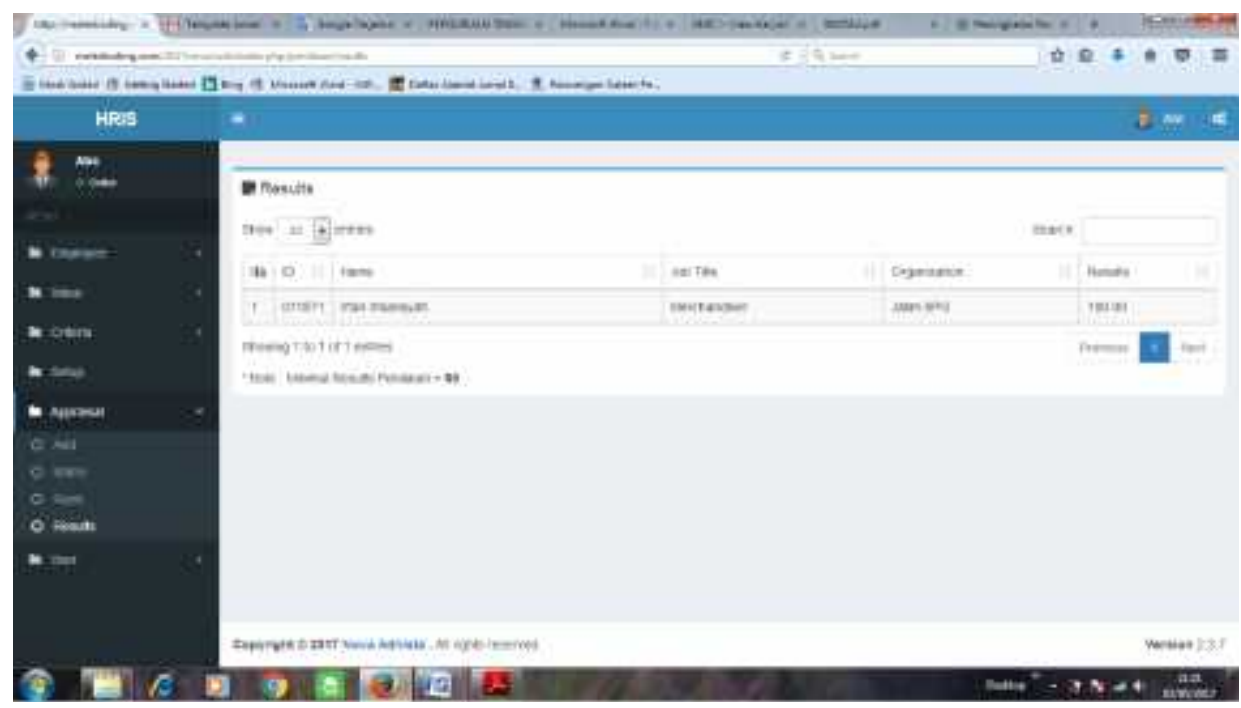

Gambar 4. Tampilan Hasil Penilaian

\section{KESIMPULAN}

1. Penilaian kinerja SPG yang ada di PT. Softex Indonesia untuk pemilihan karyawan kontrak menjadi karyawan tetap masih manual sehingga ada kemungkinan penilaian cenderung bersifat subjektif dan adanya ketidakpuasan ataupun kesalahan dalam mengambil keputusan.

2. Penulis merancang sistem pendukung keputusan penilaian kinerja karyawan SPG berstatus kontrak dalam penentuan menjadi karyawan tetap.

3. Dengan adanya aplikasi sistem pendukung keputusan penilaian kinerja SPG yang di buat menjadikan sistem penilian kinerja SPG bisa lebih efektif dan akurat.

\section{DAFTAR PUSTAKA}

[1] Rahayu, Sri, Nurhaeni, Tuti, Rohmah, Malidah “ Sistem Persediaan Alat Tulis Kantor Sebagai Penunjang Pengambilan Keputusan Bagian Logistik Di Perguruan Tinggi Raharja” CCIT Journal (2014).

[2] Kusumadewi, Sri,. 2006. "Fuzzy Multi-Attribute Decision Making (Fuzzy FAMDM)". Penerbit Graha Ilmu, Yogyakarta.

[3] Tanti, Lili, Safrizal "Meode AHP Dalam Penilian Kinerja Sales Promotion Girl” ISSN (2015)

[4] Ariyanto, 2012. "Sistem Pendukung Keputusan Pemilihan Karyawan Terbaik Dengan Metode Simple Additive Weighting (SAW) Studi Kasus Pamella Swalayan” Skripsi UIN Sunan Kalijaga, Yogyakarta

[5] Dewanto, Joko, Ignatius, Arrozi, MF. (2016) yang berjudul "Membangun Sistem Penunjang Keputusan Untuk Investasi Saham Dengan Metode Simple Additive Weighting (SAW)” SRITI 2016, Jakarta 